\title{
Sunflower productivity and gross oil production on the grey forest soil of the republic of Tatarstan under the use of growth regulators
}

\author{
Vladimir P. Vladimirov ${ }^{1}$, Evgeniy M. Chugunov ${ }^{2}$, Antonina A. Mostyakova, ${ }^{3,}$, and Arsen A. Ilgamov ${ }^{2}$ \\ ${ }^{1}$ Kazan State Agrarian University, 420015 Kazan, Russia \\ ${ }^{2}$ Tatar Institute for Continuing Education in Agricultural Business, 420059 Kazan, Russia \\ ${ }^{3}$ Kazan Federal University, 420008 Kazan, Russia
}

\begin{abstract}
An important source for increasing the sunflower yield and getting high economic efficiency consists of improving agricultural techniques for cultivation, in particular, soil and climatic conditions. Using growth regulators is one such technique. This research studies the effectiveness of the complex use of growth regulators when the treatment of seeds before planting is combined with the sprinkling of actual plants. During the whole period of the 4-year study, the maximum yield of seeds ( 3.233 tons/hectare), the highest oil content $(52.95 \%)$, and the gross oil production level $(1713.8 \mathrm{~kg} / \mathrm{hectare})$ were obtained under the use of Zirkon growth regulator.
\end{abstract}

\section{Introduction}

Within 15-20 years sunflower has become one of the main crops cultivated globally. It is a perspective oil crop for both the Russian Federation and the Republic of Tatarstan. One of the ways to increase the yield of sunflower and the effectiveness of its cultivation is to improve the agricultural techniques for a particular soil and climatic zone.

In the last years, the protection of agricultural crops has been getting complicated. This happens because protection products become more expensive while new plant diseases and pests appear. The use of high doses of products disturbs the biological equilibrium and affects the environment $[1,2]$.

Currently, the environmentalization of crop farming is gaining bigger relevance. Farmers can decrease the cost of agricultural production by using growth regulators instead of more expensive chemicals. Among growth regulators, there is a preference for natural substances produced from plants, fungi, and micro-organisms on the one hand or growth stimulators on the other hand [3-5]. The new generation growth regulators have triple action: stimulating biological processes, increasing plant resistance to unfavorable factors, and boosting non-specific immunity $[6,7]$.

Based on his research, V.P. Lukhmenev [8] argues that natural origin substances influence the metabolism of plants, changing the processes of growth and development of plants as well as increasing their resistance to stress factors.

Growth regulators can't replace fertilizers but complement them in the nutritional system of agricultural crops. They also increase the ratio of nutrients absorbed from the soil and fertilizers $[1,9]$.

Currently, the major gap between potential and actual sunflower yield makes scientists search for ways to eliminate it in conditions of particular regions.

This research mainly aims at finding ways to increase sunflower productivity using growth stimulators to treat seeds and plants in the Zakamye region of the Republic of Tatarstan.

The achievement of this aim requires studying the influence of different regulators on the growth, development, yield, and content of fat in sunflower seeds.

\section{Conditions, materials, and methods of research}

The research was carried out in 2015-2018 on the experimental fields of the department of crop production and horticulture at Kazan Federal University. The land of the experimental plot is of forest type with middle loamy, granulometric texture. The salt extract $\mathrm{pH}$ is 5.5-5.7. The nutritional properties of soil are the following: humus level is $5.1-5.6 \%$, labile phosphorus content is 126-146, exchange potassium content is $142-161 \mathrm{mg} / \mathrm{kg}$ of soil. The preceding crop is winter wheat. The total area of the plot is $280 \mathrm{~m}^{2}$, while the accounting area is $140 \mathrm{~m}^{2}$. The agricultural methods used in the experiment are common for this region. The ratio of introduced mineral fertilizers is $\mathrm{N}_{70} \mathrm{P}_{50} \mathrm{~K}_{70}$.

The seeds in the research were treated with the following regulators: Albit $-30 \mathrm{ml} / \mathrm{t}$, Biosil $-40 \mathrm{ml} / \mathrm{t}$,

* Corresponding author: runga540@mail.ru 
Epin-extra - $4 \mathrm{ml} / \mathrm{t}$, Zirkon - $4 \mathrm{ml} / \mathrm{t}$. The consumption rate of water solution was $10 \mathrm{l} / \mathrm{g}$.

At the stage of 2-4 true leaves we sprinkled the plants with Albit - $30 \mathrm{ml} / \mathrm{t}$, Biosil - $40 \mathrm{ml} / \mathrm{t}$, Epin-extra $4 \mathrm{ml} / \mathrm{t}$, Zirkon $-4 \mathrm{ml} / \mathrm{t}$. The consumption rate of water solution was 200 1/hectare.

\section{The aim and tasks of research}

The research aimed at increasing the yield of seeds and the content of oil using different ways for growth regulation under the conditions of grey forest soils of the Zakamye region in the Republic of Tatarstan.

\section{Research tasks:}

- find the influence of growth regulators on the growth and development of sunflower plants;
- determine the dependency between the yield and the oil content of sunflower from applying growth regulators.

\section{Results and discussion}

The most important factor in getting the high yield is timely and concurrent germination of sunflower. The successful growth and development of sunflower plants depend on the right choice of growth stimulators for presowing treatment. The germination ability in different variants of the experiment varied between $89.76 \%$ for the control variant without using growth regulators and $93.83 \%$ in the case of Zirkon regulator. On average, during 4 years of research, the pre-sowing treatment of seeds with growth regulators increased the germination ability by $2.09-3.93 \%$ in comparison with the control variant (table 1).

Table 1. The number of germinated seeds and survivability of sunflower plants depending on the manner of application of growth regulators, 2015-2018

\begin{tabular}{|c|l|c|c|c|c|}
\hline Product & \multicolumn{1}{|c|}{ Treatment method } & $\begin{array}{c}\text { Number of } \\
\text { germinated } \\
\text { seeds, } \\
\text { thousand } \\
\text { seedlings per } \\
\text { hectare }\end{array}$ & $\begin{array}{c}\text { Germination } \\
\text { rate, } \%\end{array}$ & $\begin{array}{c}\text { Number of } \\
\text { plants } \\
\text { before } \\
\text { harvesting, } \\
\%\end{array}$ & $\begin{array}{c}\text { Plant } \\
\text { survivabilit } \\
\text { y, }\end{array}$ \\
& & 58.39 & 89.76 & 55.10 & 94.34 \\
\hline \multirow{2}{*}{ Control } & & 59.70 & 91.85 & 56.75 & 95.06 \\
\hline \multirow{2}{*}{ Albit } & Treatment of seeds & 58.74 & 90.37 & 55.91 & 95.14 \\
\cline { 2 - 6 } & Sprinkling of plants & 59.97 & 92.26 & 57.30 & 95.53 \\
\cline { 2 - 6 } & Treatment of seeds + sprinkling of plants & 60.24 & 92.68 & 56.97 & 94.72 \\
\hline \multirow{3}{*}{ Biosil } & Treatment of seeds & 59.01 & 90.79 & 56.35 & 94.68 \\
\cline { 2 - 6 } & Sprinkling of plants & 60.50 & 93.08 & 57.83 & 95.56 \\
\cline { 2 - 6 } & Treatment of seeds + sprinkling of plants & 60.27 & 92.72 & 56.98 & 94.52 \\
\hline \multirow{2}{*}{ Epin- } & Treatment of seeds & 58.69 & 90.28 & 55.74 & 94.95 \\
\cline { 2 - 6 } & Sprinkling of plants & 60.44 & 92.98 & 57.66 & 95.39 \\
\cline { 2 - 6 } & Treatment of seeds + sprinkling of plants & 60.9 & 93.69 & 58.08 & 95.36 \\
\hline \multirow{2}{*}{ Zirkon } & Treatment of seeds & 59.13 & 91.72 & 56.32 & 95.23 \\
\cline { 2 - 6 } & Sprinkling of plants & 60.99 & 93.83 & 58.23 & 96.27 \\
\cline { 2 - 6 } & Treatment of seeds + sprinkling of plants & & & \\
\hline
\end{tabular}

Table 2. The surface of sunflower leaves depending on the manner of application of growth regulators, 2015-2018

\begin{tabular}{|c|c|c|c|c|}
\hline \multirow[b]{2}{*}{ Product } & \multirow[b]{2}{*}{ Treatment method } & \multicolumn{3}{|c|}{ Sunflower plant development stage } \\
\hline & & budding & anthesis & $\begin{array}{l}\text { economic } \\
\text { maturity }\end{array}$ \\
\hline Control & - & 22.48 & 39.54 & 7.64 \\
\hline \multirow[t]{3}{*}{ Albit } & Treatment of seeds & 27.94 & 42.52 & 8.04 \\
\hline & Sprinkling of plants & 27.65 & 41.61 & 8.66 \\
\hline & Treatment of seeds + sprinkling of plants & 29.62 & 43.05 & 9.02 \\
\hline \multirow[t]{3}{*}{ Biosil } & Treatment of seeds & 28.16 & 41.48 & 7.95 \\
\hline & Sprinkling of plants & 27.25 & 40.64 & 7.98 \\
\hline & Treatment of seeds + sprinkling of plants & 29.11 & 42.72 & 8.11 \\
\hline \multirow{3}{*}{$\begin{array}{l}\text { Epin- } \\
\text { extra }\end{array}$} & Treatment of seeds & 28.74 & 42.88 & 8.14 \\
\hline & Sprinkling of plants & 27.82 & 41.58 & 7.96 \\
\hline & Treatment of seeds + sprinkling of plants & 27.62 & 44.24 & 9.15 \\
\hline \multirow[t]{3}{*}{ Zirkon } & Treatment of seeds & 30.36 & 45.16 & 9.46 \\
\hline & Sprinkling of plants & 29.72 & 44.86 & 9.24 \\
\hline & Treatment of seeds + sprinkling of plants & 32.65 & 46.28 & 9.66 \\
\hline
\end{tabular}

The survivability of sunflower seeds before harvesting was quite high. Even in the control variant without treatment by growth regulators, it was $92.99 \%$. The highest survivability $(96.27 \%)$ was in the case of combined treatment with Zirkon (treatment of seeds + treatment of plants).

A.A. Nichiporovich $[10,11]$ and T.N. Kulakovskaya [12] indicate that high yields are formed only in the case 
of the optimal surface of foliage which remains active during vegetation and uses accumulated macronutrients to form productive plant organs.

While studying sunflower hybrids, V.S. Seferyan [13] found that the maximum surface of foliage (17.85-28.00 thousand $\mathrm{m}^{2} /$ hectare) formed at the stage of anthesis. The surface then decreased due to the death of lower leaves. The same results were obtained by A.V. Germogenov [14], who denotes that the foliage surface grew most intensively before anthesis. After reaching the maximum value, it started to decrease gradually when lower leaves started dying.

The formation of the assimilative surface in the case of sunflower plantlets was influenced by different factors, including growth regulators.

In our studies, the foliage surface was quite large already at the stage of budding. It varied between 22.48 thousand $\mathrm{m}^{2} /$ hectare in the control variant and 32.65 thousand $\mathrm{m}^{2} /$ hectare in the case of treatment by Zirkon (table 2).

The maximum surface of foliage (39.54-46.28 thousand $\mathrm{m}^{2} /$ hectare) formed at the anthesis stage. The efflux of nutrients started from lower leaves that gradually became dry. By the time of economic maturity, the foliage surface had significantly decreased.

The value of the foliage surface was influenced by growth regulators. Regardless of the used method, they had a great impact on its increase. For example, the foliage surface in the control variant was 39.54 thousand $\mathrm{m}^{2} /$ hectare. After treatment by Albit, it increased by 2.07-3.51 thousand $\mathrm{m}^{2} /$ hectare depending on the use manner. The treatment by Zirkon was the most effective. In its case, the value of the surface grew by $5.32-6.74$ thousand $\mathrm{m}^{2} /$ hectare depending on the use manner.

The research showed that growth regulators have some impact on the yield of sunflower seeds. If the yield in the control variant was $2.425 \mathrm{t} /$ hectare during 4 years of experiment, the use of growth regulators even in small doses increased it.

In this case, Zirkon was the most effective with the yield of 3.223-2.911 t/hectare depending on the use manner. On average the increase of yield during 4 years of research was $0.486 \mathrm{t} /$ hectare in the case of plant treatment and $0.798 \mathrm{t} /$ hectare in the case of combined (seeds + plants) treatment (Table 3).

In the case of Albit, the yield was 2.715-2.964 tons per hectare depending on the use manner. The increase in comparison with the control variant was 0.290-0.539 tons/hectare. The research showed that growth regulators also impact the content of the oil. According to our data, their influence in field conditions is due to external factors. There is a dependency between the percentage of oil, the meteorological conditions during vegetation, and the use of regulators.

Table 3. The yield of sunflower seeds depending on the manner of application of growth regulators, 2015-2018

\begin{tabular}{|c|c|c|c|c|c|c|}
\hline \multirow[t]{2}{*}{ Product } & \multirow[t]{2}{*}{ Treatment method } & \multicolumn{5}{|c|}{ Yield, tons per hectare } \\
\hline & & 2015 & 2016 & 2017 & 2018 & average \\
\hline Control & - & 2.952 & 2.658 & 1.524 & 2.564 & 2.425 \\
\hline \multirow[t]{3}{*}{ Albit } & Treatment of seeds & 3.282 & 3.114 & 1.616 & 3.021 & 2.758 \\
\hline & Sprinkling of plants & 3.236 & 2.876 & 1.784 & 2.962 & 2.715 \\
\hline & Treatment of seeds + sprinkling of plants & 3.442 & 3.164 & 2.016 & 3.232 & 2.964 \\
\hline \multirow[t]{3}{*}{ Biosil } & Treatment of seeds & 3.244 & 2.984 & 1.576 & 3.234 & 2.760 \\
\hline & Sprinkling of plants & 3.198 & 2.675 & 1.590 & 3.008 & 2.618 \\
\hline & Treatment of seeds + sprinkling of plants & 3.308 & 3.165 & 1.846 & 3.315 & 2.909 \\
\hline \multirow{3}{*}{$\begin{array}{l}\text { Epin- } \\
\text { extra }\end{array}$} & Treatment of seeds & 3.414 & 3.034 & 1.719 & 3.224 & 2.848 \\
\hline & Sprinkling of plants & 3.362 & 2.784 & 1.735 & 3.117 & 2.750 \\
\hline & Treatment of seeds + sprinkling of plants & 3.446 & 3.286 & 1.982 & 3.315 & 3.007 \\
\hline \multirow[t]{3}{*}{ Zirkon } & Treatment of seeds & 3.512 & 3.268 & 1.888 & 3.228 & 2.974 \\
\hline & Sprinkling of plants & 3.434 & 3.122 & 1.962 & 3.125 & 2.911 \\
\hline & Treatment of seeds + sprinkling of plants & 3.702 & 3.445 & 2.224 & 3.521 & 3.223 \\
\hline \multicolumn{2}{|l|}{$\mathrm{LSD}_{05} \quad \mathrm{~A}$} & 0.08 & 0.06 & 0.08 & 0.06 & \\
\hline \multicolumn{2}{|l|}{$\mathrm{LSD}_{05} \mathrm{~B}$} & 0.04 & 0.04 & 0.02 & 0.02 & \\
\hline \multicolumn{2}{|l|}{$\mathrm{LSD}_{05} \quad \mathrm{AB}$} & 0.07 & 0.14 & 0.11 & 0.11 & \\
\hline
\end{tabular}

Table 4. The content of oil in seeds depending on the manner of application of growth regulators, 2015-2018

\begin{tabular}{|c|l|c|c|c|c|c|}
\hline \multirow{2}{*}{ Product } & \multicolumn{5}{|c|}{ Oil content, \% } \\
\cline { 3 - 7 } & & 2015 & 2016 & 2017 & 2018 & average \\
\hline \multirow{2}{*}{ Control } & & 53.62 & 51.43 & 47.57 & 52.46 & 51.27 \\
\hline \multirow{2}{*}{ Albit } & Treatment of seeds & 54.24 & 51.72 & 49.54 & 53.22 & 52.18 \\
\cline { 2 - 7 } & Sprinkling of plants & 53.81 & 51.62 & 49.50 & 52.72 & 51.91 \\
\cline { 2 - 7 } & Treatment of seeds + sprinkling of plants & 54.63 & 52.12 & 49.74 & 53.60 & 52.52 \\
\hline \multirow{2}{*}{ Biosil } & Treatment of seeds & 53.82 & 51.54 & 50.12 & 52.86 & 52.09 \\
\cline { 2 - 7 } & Sprinkling of plants & 53.53 & 51.32 & 50.21 & 52.58 & 51.91 \\
\cline { 2 - 7 } & Treatment of seeds + sprinkling of plants & 54.14 & 51.83 & 50.44 & 53.18 & 52.40 \\
\hline \multirow{2}{*}{ Epin-extra } & Treatment of seeds & 53.92 & 51.83 & 49.37 & 52.96 & 52.02 \\
\cline { 2 - 7 } & Sprinkling of plants & 53.74 & 51.62 & 49.22 & 52.24 & 51.71 \\
\cline { 2 - 7 } & Treatment of seeds + sprinkling of plants & 54.41 & 51.74 & 49.68 & 53.12 & 52.19 \\
\hline \multirow{2}{*}{ Zirkon } & Treatment of seeds & 54.43 & 52.14 & 50.22 & 53.18 & 52.49 \\
\cline { 2 - 7 } & Sprinkling of plants & 53.92 & 51.91 & 50.34 & 52.87 & 52.26 \\
\cline { 2 - 7 } & Treatment of seeds + sprinkling of plants & 54.84 & 52.52 & 50.82 & 53.62 & 52.95 \\
\hline
\end{tabular}


The advantage of regulators is that they actively influence the metabolism of plants as well as growth, physiological, and form-building processes. The regulators also boost immunity. All this makes plants more resistible to stress situations, fungal, bacterial, and viral diseases.

The rationale behind the evaluation of oil content in kernels is explained by the fact that the oil of seed husk is different from the oil of kernels in content. Also, the percentage of huskiness varies by year which influences the percentage of oil in seeds. The content of oil varied by year. In 2015 it was higher in comparison with 2016 and 2018 and, especially, 2017 (table 4).

In the control variant of the experiment, the total production of oil for 4 years was $1254.6 \mathrm{~kg} / \mathrm{hectare}$ on average (table 5). The highest production of $1713.8 \mathrm{~kg} /$ hectare was achieved in the case of Zirkon growth regulator used for combined treatment.

Table 5. The total production of oil depending on the manner of application of growth regulators, 2015-2018

\begin{tabular}{|c|l|c|c|c|c|c|}
\hline \multirow{2}{*}{ Product } & \multicolumn{4}{|c|}{ Oil production, kg/hectare } \\
\cline { 3 - 6 } & & 2015 & 2016 & 2017 & 2018 & average \\
\hline Control & & 1582.3 & 1366.2 & 725 & 1345.0 & 1254.6 \\
\hline \multirow{2}{*}{ Albit } & Treatment of seeds & 1778.8 & 1609.9 & 800 & 1607.8 & 1449.1 \\
\cline { 2 - 6 } & Sprinkling of plants & 1741.0 & 1484.0 & 883 & 1561.6 & 1417.4 \\
\cline { 2 - 6 } & Treatment of seeds + sprinkling of plants & 1879.3 & 1648.4 & 1003 & 1732.4 & 1565.8 \\
\hline \multirow{2}{*}{ Biosil } & Treatment of seeds & 1745.3 & 1536.8 & 790 & 1709.5 & 1445.4 \\
\cline { 2 - 6 } & Sprinkling of plants & 1710.9 & 1372.3 & 798 & 1581.6 & 1365.7 \\
\cline { 2 - 6 } & Treatment of seeds + sprinkling of plants & 1789.6 & 1639.5 & 931 & 1762.9 & 1530.8 \\
\hline \multirow{3}{*}{ Epin-extra } & Treatment of seeds & 1840.1 & 1571.6 & 847 & 1707.4 & 1491.5 \\
\cline { 2 - 6 } & Sprinkling of plants & 1805.4 & 1436.5 & 854 & 1628.3 & 1431.1 \\
\cline { 2 - 6 } & Treatment of seeds + sprinkling of plants & 1874.6 & 1698.9 & 985 & 1760.9 & 1579.9 \\
\hline \multirow{2}{*}{ Zirkon } & Treatment of seeds & 1910.5 & 1702.6 & 948 & 1716.7 & 1569.5 \\
\cline { 2 - 6 } & Sprinkling of plants & 1850.9 & 1620.3 & 988 & 1652.2 & 1527.9 \\
\cline { 2 - 6 } & Treatment of seeds + sprinkling of plants & 2028.7 & 1808.6 & 1130 & 1888.0 & 1713.8 \\
\hline
\end{tabular}

\section{Conclusion}

The field germination ability of seeds strongly depended both on meteorological conditions and the use of growth regulators. The germination ability in different variants of the experiment varied between $89.76 \%$ for the control variant without using growth regulators and $93.83 \%$ in the case of Zirkon regulator. On average, during 4 years of research, the pre-sowing treatment of seeds with growth regulators increased the germination ability by $1.96-4.07 \%$ (depending on the product used) in comparison with the control variant.

The survivability of sunflower seeds before harvesting was quite high. Even in the control variant without treatment by growth regulators, it was $94.34 \%$. The highest survivability $(96.27 \%)$ was in the case of combined treatment with Zirkon (treatment of seeds + treatment of plants).

On average, all growth regulators gave an increase in yield during 4 years of research. The highest increase was in the case of Zirkon regardless of the use manner. In comparison with the control variant, the pre-sowing treatment of seeds increased the yield by $0.549 \mathrm{t} / \mathrm{hectare}$, the treatment of plants increased the yield by $0.486 \mathrm{t} / \mathrm{hectare}$, and the combination of these methods gave the increase by $0.798 \mathrm{t} /$ hectare.

The production of oil was also higher after treatment with Zirkon. In the case of the treatment of seeds, the increase was $314.0 \mathrm{~kg} / \mathrm{hectare}$. The treatment of plants raised the production of oil by $273.3 \mathrm{t} /$ hectare and the combined treatment - by $459.2 \mathrm{t} /$ hectare.

\section{References}

1. O.I. Antonova, V.A. Dekkert, S.A. Potapov, Biological agents as a means to increase the yield and quality of seeds and oilseeds of sunflower as well as sugar beet roots, Bull. of Altai State Agricultural University, 2, 9-16 (2003)

2. A.A. Zavalin, Biological agents, fertilizers, and yield (VNIIA, Moscow, 2005)

3. V.V. Vakulenko, O.A. Shapoval, New growth regulators in agricultural production, Agro XXI, 2, 2-4 (2001)

4. L.K. Ostrovskaya, Chelate compounds of metals $-a$ new type of micro-fertilizers, in Micro-elements in the USSR (Riga, 1984)

5. V.N. Petrichenko, Micro-elements in horticulture (Nauka, Moscow, 1998)

6. L.D. Prusakova, N.N. Malevannaya, S.Yu. Belopukhov, V.V. Vakulenko, Growth regulators with antistress and immunity protection properties, Agricult. chem., 11, 76-86 (2005)

7. N.P. Burdikina, T.F. Alekseeva, N.I. Chilkov, The evaluation of the biological potential of new growth regulators, Agrochemistry bulletin, 6, 24-25 (2007)

8. V.P. Lukhmenev, The influence of fertilizers, fungicides, and growth regulators on sunflower productivity, Proceedings of Orenburg State Agrar. Univer., 1, 41-46 (2015)

9. Yu.S. Kolyagin, O.V. Novichikhin, The influence of root nutrition on the growth and yield of sunflower, Agrar. sci., 10, 15-16 (2011) 
10. A.A. Nichiporovich, The theoretical basis for plant productivity enhancement, in Plant physiology, vol. 3, 13-15 (Moscow, 1977)

11. A.A. Nichiporovich, Photosynthesis and theory for obtaining high yields, 19-31 (Moscow, 1965)

12. T.N. Kulakovskaya, The optimization of the agrochemical system of soil nutrition of plants (Agropromizdat, Moscow, 1990)
13. V.S. Seferyan, The productivity of sunflower hybrids depending on preceding crops, seeding time, and fertilizers under the conditions of southern chernozem in the Volgograd region (Volgograd, 2005)

14. A.V. Germogenov, Agricultural and biological features and cultivation techniques for cultivating sunflower varieties and hybrids with a high content of oil on dark brown soils of Volgograd region (Volgograd, 2004) 